\title{
Soil factors determining the distribution of Phragmites australis and Phacelurus latifolius in upper tidal zone
}

\author{
Bo Eun Nam, Mun Gi Hong, Hyun Jun Park and Jae Geun Kim (D)
}

\begin{abstract}
To assess the environmental factors determining the zonation between Phacelurus latifolius and Phragmites australis, vegetation survey and soil analysis were performed at a tidal marsh. The vegetation of the tidal marsh was classified into P. latifolius and Suaeda japonica dominated quadrats, P. latifolius and P. australis dominated quadrats, P. australis dominated quadrats, and $P$. australis and other land plants dominated quadrats. The density of P. latifolius (83.7 \pm 5.5 shoots $\mathrm{m}^{-2}$ ) was higher than that of $P$. australis $\left(79.3 \pm 12.1\right.$ shoots $\mathrm{m}^{-2}$ ) in each dominated quadrat but height of two species were similar. Soil environmental characteristics of $P$. latifolius dominated quadrats appeared to be affected by tide based on higher soil electric conductivity $\left(E C_{P L}=1530 \pm 152 \mu \mathrm{cm}^{-1} ; E C_{P A}+P L=689 \pm 578 \mu \mathrm{cm}^{-1}\right.$; $E C_{P A}=689 \pm$ $578 \mu \mathrm{cm}^{-1}$ ) and lower $\mathrm{pH}\left(\mathrm{pH}_{\mathrm{PL}}=5.96 \pm 0.16 ; \mathrm{pH}_{\mathrm{PA}}+\mathrm{PL}=6.28 \pm 0.31 ; \mathrm{PH}_{\mathrm{PA}}=6.38 \pm 0.22\right)$. In redundancy analysis, environmental characteristics of $P$. latifolius dominated quadrats and $P$. australis dominated quadrats were clearly separated and those of $P$. latifolius and $P$. australis co-dominated quadrats were similar to $P$. australis dominated quadrats. From our investigation, $P$. latifolius showed relatively high competitiveness when compared to $P$. australis in lower tidal zone rather than upper tidal zone. Zonation of $P$. latifolius and $P$. australis seems to be a transitional zone between halophytes and land plant species.
\end{abstract}

Keywords: Common reed, Halophytes, Redundancy analysis, Soil salinity, Tidal channel

\section{Background}

Tidal marshes, showing high primary productivity, usually function as buffer zone, water purifier, and habitat for wildlife (Moeller et al. 1996; Wolters et al. 2005; Bang et al. 2018). Many ecological functions of tidal marsh are based on the growth of plant species. Since salinity and water flooding act as a selective pressure in tidal marsh, only a few plant species could inhabit in tidal marsh when compared to other types of wetland (Ihm et al. 2006; Isacch et al. 2006). Thus, adaptive mechanisms to the saline and frequently inundated soil such as salt excretion are necessary to plant species for inhabiting in tidal marsh.

Due to seawater flooding regime causing heterogeneous environments in tidal marsh, zonation patterns of vegetation often occur depending on soil environments particularly in rhizosphere (Armstrong et al. 1985; Ihm

* Correspondence: jaegkim@snu.ac.kr

Department of Biology Education, Seoul National University, Seoul 08826, Republic of Korea

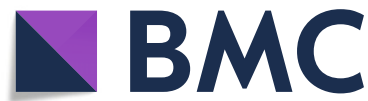

et al. 2006; Bang et al. 2018). Grass species mainly occur in the temperate zone of tidal marsh (Ihm et al. 2001, 2006). In upper tidal zone, for example, common reed (Phragmites australis (Cav.) Trin. ex Steud.) is the most common and dominant species that contributes to productivity and landscape. Suaeda spp. such as Suaeda glauca (Bunge) Bunge and Suaeda japonica Makino are common halophytes, which inhabit only at lower part of tidal zone in East Asia (Lee et al. 2016).

In tidal marsh of East Asia, Phacelurus latifolius (Steud.) Ohwi has also occurred with $P$. australis (Yokoyama et al. 2003; Min 2015). Both species show high standing crop and similar stand in tidal marsh (Lee 2003). P. latifolius is classified as halophytes, while $P$. australis is classified as salt-tolerant species (Lissner and Schierup 1997; Yokoyama et al. 2003). According to salinity ranges, two species have shown the zonation pattern in tidal marsh (Yokoyama et al. 2003; Bang et al. 2018). Despite different niche in the salinity range of $P$.

(c) The Author(s). 2018 Open Access This article is distributed under the terms of the Creative Commons Attribution 4.0 International License (http://creativecommons.org/licenses/by/4.0/), which permits unrestricted use, distribution, and reproduction in any medium, provided you give appropriate credit to the original author(s) and the source, provide a link to the Creative Commons license, and indicate if changes were made. The Creative Commons Public Domain Dedication waiver (http://creativecommons.org/publicdomain/zero/1.0/) applies to the data made available in this article, unless otherwise stated. 
latifolius and $P$. australis, those species occasionally co-occur in an area (Min 2015).

Quantitative analyses on soil physicochemical properties are important for understanding the environmental ranges of individual species in tidal marsh. Nevertheless, only a few studies have been performed about the co-existence of $P$. australis and $P$. latifolius in tidal marsh focusing on the environmental distribution range of two species only in elevation and physical properties of soil (Yokoyama et al. 2003; Min 2015). To investigate the soil environmental factors determining the zonation between $P$. australis and $P$. latifolius in tidal marsh, distributional characteristics and soil physicochemical properties were surveyed.

\section{Methods}

\section{Study site and vegetation survey}

Field survey was conducted at a tidal marsh in the tidal channel of Siheung City, Gyeonggi Province, Republic of Korea $\left(37^{\circ} 24^{\prime} \mathrm{N} 126^{\circ} 45^{\prime} \mathrm{E}\right)$ in July 2016 , when the flowering bud of $P$. latifolius was emerged. Two or three quadrats in each of 11 transverse lines along the zonation of $P$. latifolius and $P$. australis were surveyed (total 31 quadrats; Fig. 1). Average height, density, and coverage of every species which emerged in the $1 \mathrm{~m} \times 1 \mathrm{~m}$ quadrat were surveyed. Soil samples were collected in $30 \sim 40 \mathrm{~cm}$ depth (near the rhizosphere of $P$. latifolius or $P$. australis) at each quadrat at low tide.

\section{Soil analysis}

Soil samples were air-dried and passed through a 2 -mm-mesh sieve. Soil moisture was measured by loss of mass after drying at $105{ }^{\circ} \mathrm{C}$ oven for $24 \mathrm{~h}$ (or $48 \mathrm{~h}$ ), and organic matter content $(\mathrm{OM})$ was calculated by the loss-on-ignition method at $550{ }^{\circ} \mathrm{C}$ furnace (Boyle 2004). Soil electric conductivity and $\mathrm{pH}$ were measured by the mixture of soil samples with distilled water at 1:5 ratio (conductivity meter: Corning Checkmate II, Corning, Lowell, MA; pH meter: AP63, Fisher, Hampton, USA).
Soil $\mathrm{NO}_{3}-\mathrm{N}$ and $\mathrm{NH}_{4}-\mathrm{N}$ content were measured by hydrazine method and indophenol method from the extract using $2 \mathrm{M} \mathrm{KCl}$ solution at 1:5 ratio, respectively (Kamphake et al. 1967; Kim et al. 2004). Soil $\mathrm{PO}_{4}-\mathrm{P}$ content was measured by a Bray No. 1 method (Bray and Kurtz 1945) from the extract with Bray No. 1 solution. Available cations $\left(\mathrm{K}^{+}, \mathrm{Ca}^{2+}, \mathrm{Na}^{+}\right.$, and $\left.\mathrm{Mg}^{2+}\right)$ were extracted with $1 \mathrm{~N}$ ammonium acetate solution (Allen et al. 1974), and contents were measured by an atomic absorption spectrophotometer (AA240FS, Varian, Palo Alto, USA). Soil particle composition, sand, silt, and clay contents were examined by hydrometer method (Carter 1993).

\section{Statistical analysis}

TWINSPAN analysis for community ordination and redundancy analysis (RDA) were performed by $\mathrm{R}$ version 3.3.3 (R Core Team 2016) with "twinspanR" and "vegan" package, respectively. Vegetation cover was used in TWINSPAN analysis. Hellinger-transformated vegetation cover and raw soil environmental variables were used in RDA. Analysis of variance and Duncan's post hoc test of soil environmental variables were also conducted using R with "agricolae" package.

\section{Results}

Phacelurus latifolius dominated quadrats were distributed in the relatively lower part of the tidal marsh than $P$. australis dominated quadrats. $P$. latifolius and $P$. australis co-dominated quadrats by two species were distributed between dominated areas of each two species. Average shoot height of $P$. latifolius and P. australis was similar as about $150 \mathrm{~cm}$ (Fig. 2a). Those two species grew about $2 \mathrm{~m}$ at the end of the growing season. Average density was slightly higher in P. latifolius dominated quadrats (Fig. 2b). In P. latifolius and P. australis dominated quadrats, density of two species was relatively low, while average height of each species was similar to the each dominated quadrat.

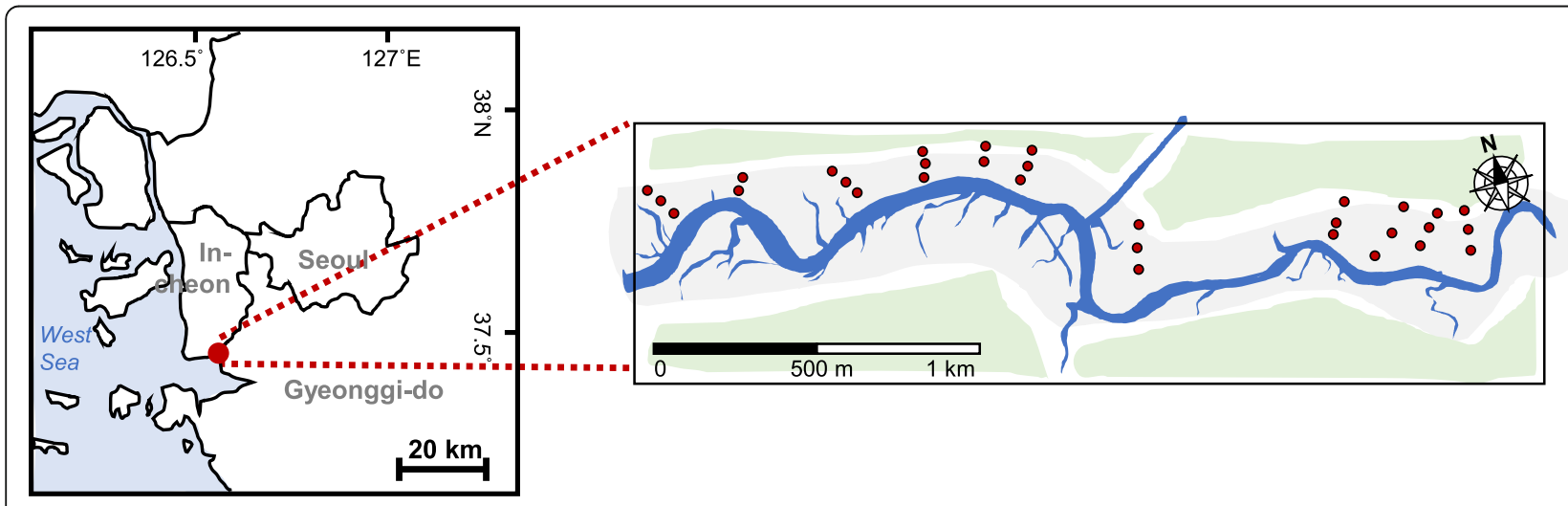

Fig. 1 Map of study site. Red closed circles indicate the location of quadrats 

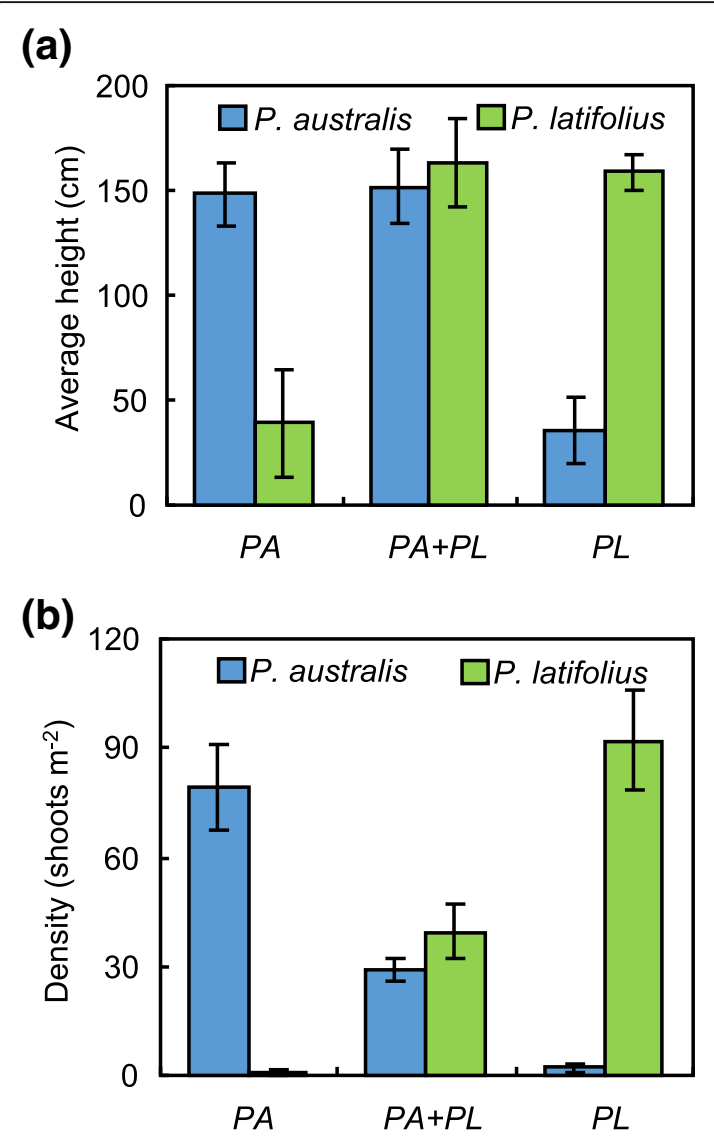

(c)

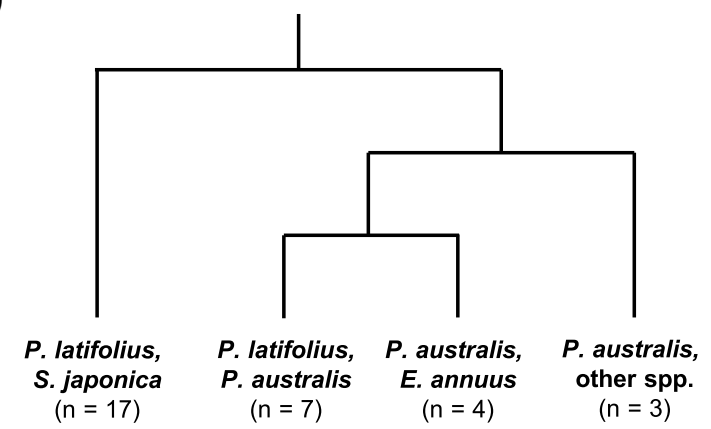

Fig. 2 Distribution characteristics of Phacelurus latifolius and Phragmies australis in a tidal marsh. a Average height in quadrat. b Shoot density. c Ordination based on species composition by TWINSPAN. PA P. australis dominated, PL P. latifolius dominated, PA + PL $P$. australis and $P$. latifolius co-dominated quadrats

As a result of TWINSPAN ordination, quadrats were classified into $P$. latifolius and Suaeda japonica community and other communities with $P$. australis (Fig. 2c). Major co-occurred species with P. australis was P. latifolius or Erigeron annuus (L.) Pers. (daisy fleabane), mainly occurs in land ecosystem (Lee 2003). Species composition of $P$. australis and $E$. annuus community or $P$. australis and other species community were similar to the terrestrial ecosystem rather than tidal marsh.

In proximity to the seawater, physicochemical properties of $P$. latifolius dominated quadrats were similar to the seawater rather than $P$. australis dominated and $P$. latifolius and $P$. australis dominated quadrats. P. latifolius dominated quadrats had the highest electric conductivity $\left(1530 \pm 152 \mu \mathrm{S} \mathrm{cm}{ }^{-1}\right)$ and the lowest $\mathrm{pH}(5.96$ \pm 0.16 ) rather than other two groups (Fig. 3A, B). Clay, silt, and sand contents were similar among the three groups (Fig. 3C).

Soil moisture content was also the highest in $P$. latifolius dominated quadrats $(26.1 \pm 1.7 \%)$, and $P$. australis dominated quadrats $(24.0 \pm 2.0 \%)$ and $P$. latifolius and $P$. australis co-dominated quadrats $(20.8 \pm 0.9 \%)$ were followed (Fig. 3D). Soil organic matter content was similar among the three groups. Soil $\mathrm{PO}_{4}-\mathrm{P}$ content was the highest in $P$. latifolius dominated quadrats $\left(\mathrm{PO}_{4}-\mathrm{P}_{\mathrm{PL}}=13.0 \pm 1.7 \mathrm{mg} \quad \mathrm{kg}^{-1} ; \quad \mathrm{PO}_{4}-\mathrm{P}_{\mathrm{PA}+\mathrm{PL}}=6.8 \pm\right.$ $0.6 \mathrm{mg} \mathrm{kg}{ }^{-1} ; \mathrm{PO}_{4}-\mathrm{P}_{\mathrm{PA}}=8.7 \pm 1.3 \mathrm{mg} \mathrm{kg}{ }^{-1}$; Fig. 3E). Soil $\mathrm{NH}_{4}-\mathrm{N}$ and $\mathrm{NO}_{3}-\mathrm{N}$ content was similar among the three groups. Soil sodium content was the highest in P. latifolius dominated quadrats $\left(\mathrm{PL}=2619 \pm 230 \mathrm{mg} \mathrm{kg}^{-1}\right.$; $\left.\mathrm{PL}+\mathrm{PA}=1219 \pm 738 \mathrm{mg} \mathrm{kg}^{-1} ; \mathrm{PA}=1301 \pm 439 \mathrm{mg} \mathrm{kg}{ }^{-1}\right)$, which showed similar pattern with soil electric conductivity (Fig. 3F). Other exchangeable cation contents $\left(\mathrm{K}^{+}, \mathrm{Ca}^{2+}\right.$, $\mathrm{Mg}^{2+}$ ) were similar among the three groups.

Redundancy analysis showed that soil environmental characteristics of $P$. latifolius dominated quadrats and $P$. australis dominated quadrats could be separated by ordination (Fig. 4a). P. australis dominated or P. latifolius and $P$. australis co-dominated quadrats showed the higher $\mathrm{pH}$ or calcium content than $P$. latifolius dominated quadrats, while they were characterized by the higher soil ion contents caused by saline water.

\section{Discussion}

From the results of the field survey and ordination, generalized zonation pattern could be described as $[S$. japonica $]-[P$. latifolius $]-[P$. latifolius and $P$. australis $]$ - [P. australis and other land plants] from the relatively lower to upper tidal zone (Fig. 4b). Soil environmental characteristics of $P$. latifolius and $P$. australis dominated quadrats were similar to $P$. australis dominated quadrats rather than $P$. latifolius dominated quadrats, whereas the environmental characteristics of $P$. latifolius and $P$. australis co-dominated quadrats were varied. P. latifolius dominated quadrats showed higher electric conductivity, soil $\mathrm{Na}^{+}$and $\mathrm{PO}_{4}-\mathrm{P}$ content and lower $\mathrm{Ca}^{2+}$ content than $P$. australis dominated or P. latifolius and P. australis co-dominated quadrats.

Soil environmental characteristics such as soil salinity, total nitrate, and clay content of $P$. australis in tidal marsh were significantly lower than the soil environment 


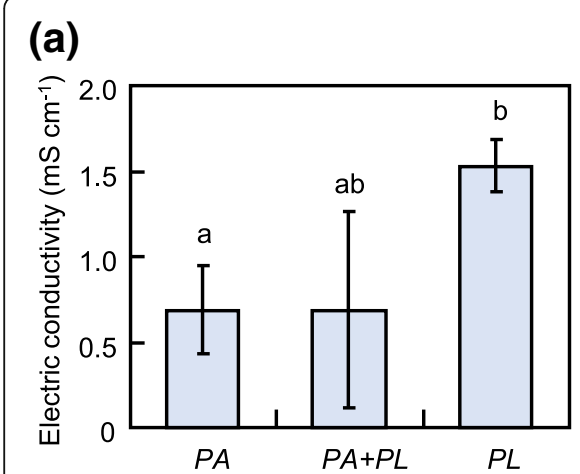

(b)

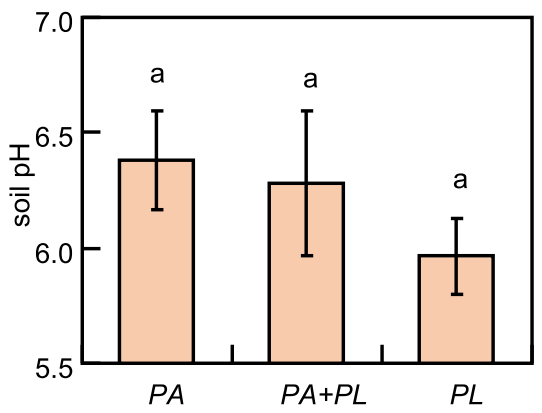

(d)

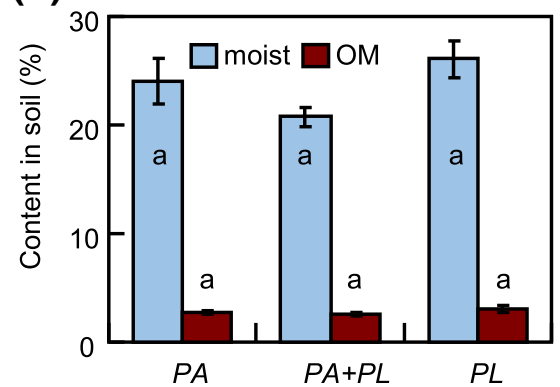

(e)

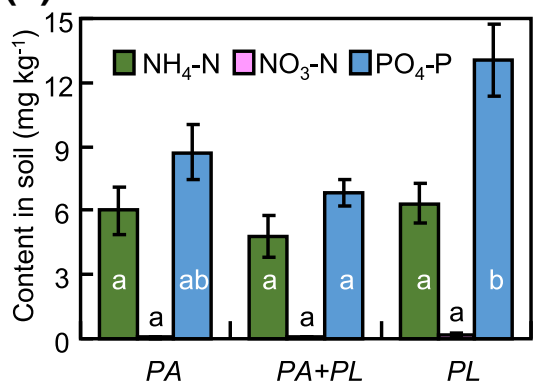

(c)

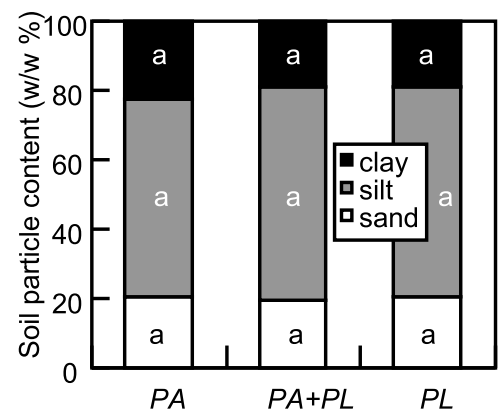

(f)

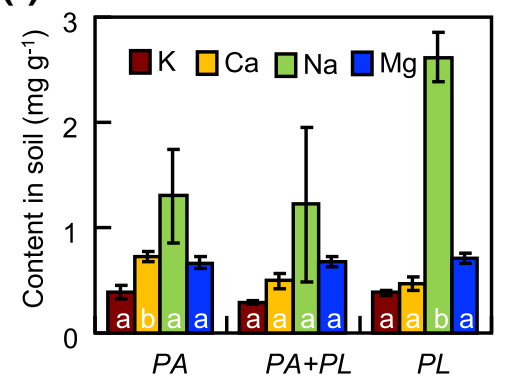

Fig. 3 Soil characteristics of Phragmites australis dominated (PA), Phragmites latifolius dominated (PL), and $P$. latifolius and $P$. australis codominated $(\mathrm{PA}+\mathrm{PL})$ quadrats in the tidal marsh. A Electric conductivity. $\mathbf{B} \mathrm{pH}$. C Soil texture. D Moisture and organic matter content (OM). E Major nutrient $\left(\mathrm{NH}_{4}-\mathrm{N}, \mathrm{NO}_{3}-\mathrm{N}, \mathrm{PO}_{4}^{-} \mathrm{P}\right)$. F Exchangeable cations $\left(\mathrm{K}^{+}, \mathrm{Ca}^{2+}, \mathrm{Na}^{+}, \mathrm{Mg}^{2+}\right)$. Letters on the bar indicate statistically different sub-groups by Duncan's post hoc test in $p<0.05$ significance range

of Suaeda community in lower area (Lee et al. 2016, 2018). Overall soil pH, electric conductivity, and other exchangeable cation concentrations were lower than the previous studies on the tidal marsh (Ihm et al. 2007; Lee et al. 2016). Plant community and soil of the studied tidal channel seemed to likely be classified as estuaries, which affected by seawater tide and freshwater output. Not only the tide affected the soil environment of zonation between $P$. australis and P. latifolius, but also the freshwater input seemed to affect the soil. In the present (a)

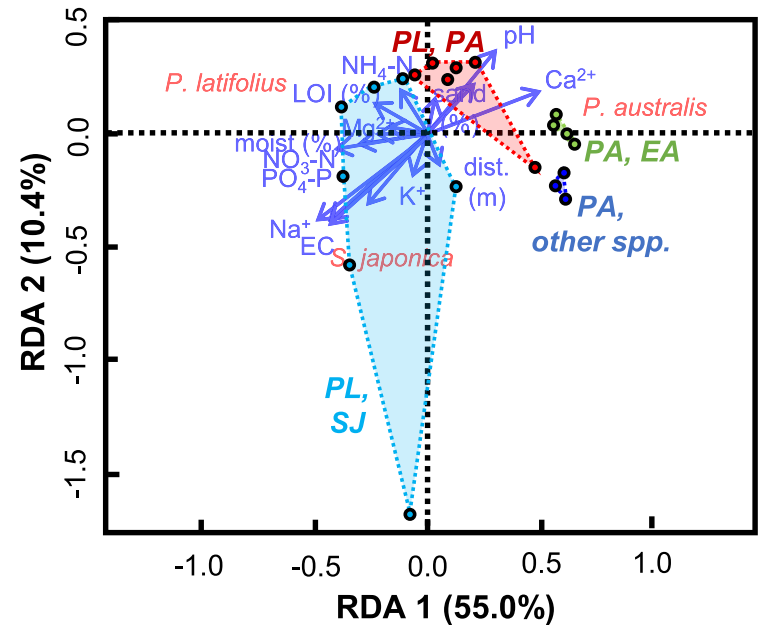

(b)

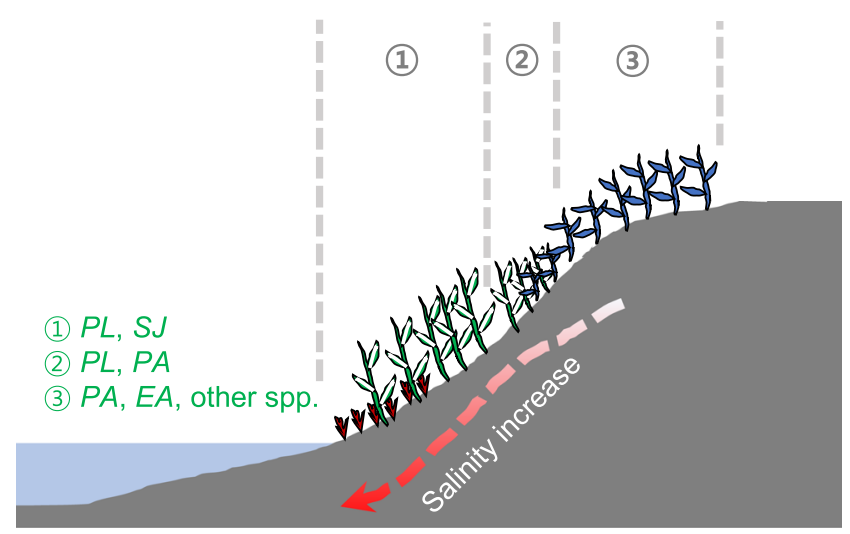

Fig. 4 a Ordination result based on the community structure and environmental characteristics using redundancy analysis (RDA). b Schematic diagram of the distribution between Phacelurus latifolius (PL) and Phragmites australis (PA) 
study, soil environmental characteristics of $P$. australis and $P$. latifolius did not show the difference in soil nitrate content or particle content. According to the narrower difference in soil environment, distribution range of $P$. australis and $P$. latifolius seemed to be restricted and almost overlapped only in the upper tidal marsh (Yokoyama et al. 2003; Bang et al. 2018).

Despite the overlapped distribution ranges by elevation of $P$. australis and P. latifolius (Bang et al. 2018), the co-existence range was narrower in this study. Min (2015) showed that $P$. australis and P. latifolius could co-exist in same tidal mound without the belowground competition by rhizome of $P$. australis which rooted deeper than $P$. latifolius. It has been reported that $P$. australis could inhabit in tidal marsh and even thrive when freshwater inflows (Lissner and Schierup 1997; Hong 2015). In spite of that, P. latifolius could exist in the more upper tidal zone than $P$. australis (Yokoyama et al. 2003; Bang et al. 2018); P. latifolius could not outcompete $P$. australis at the upper tidal zone in this study. Plant growth in the lower tidal zone is mainly restricted by saline soil than interspecific competition, whereas interspecific competition is major in the upper tidal zone by reduced environmental stress (Crain et al. 2004). Therefore, it could be supposed that competitiveness of $P$. latifolius is stronger in relatively lower tidal zone by active salt excretion mechanism, whereas $P$. australis is competitive only in the relatively upper zone where the effect of seawater is weak.

Soil salinity, which is represented by the electric conductivity, and soil $\mathrm{pH}$ were the key factors that determine the distribution of $P$. australis and $P$. latifolius. Regardless of that $P$. latifolius inhabited in the relative saline soil environment than $P$. australis, soil electric conductivity and $\mathrm{pH}$ range of $P$. latifolius dominated habitat were narrower than those of $P$. australis dominated. Considering that $P$. australis dominated habitat consists of terrestrial plant species, zonation of $P$. latifolius and $P$. australis seemed to be a transitional zone between halophytes and land plant species. Our result could provide information of the soil environmental range of large macrophyte vegetation in the salt marsh restoration.

\section{Abbreviations \\ PA: Phragmites australis; PL: Phacelurus latifolius}

\section{Acknowledgements}

Not applicable.

\section{Funding}

This research was supported by the Basic Science Research Program through the National Research Foundation of Korea (NRF) funded by the Ministry of Education (NRF-2015R1D1A1A01057373), the National Research Foundation of Korea (NRF) grant funded by the Korea government (MSIT) (NRF2018R1A2B2002267), and R\&E program of Siheung Education Institute for Gifted.

\section{Availability of data and materials}

The datasets during and/or analyzed during the current study are available from the corresponding author on reasonable request.

\section{Authors' contributions}

BEN participated in the design of the study, field survey and sampling, environmental analysis experiment, and data analyses and wrote the manuscript draft. MGH participated in the design of the study, field survey, and data analyses and edited the manuscript draft. HJP participated in the field survey and sampling and environmental analysis experiment. JGK conceived the study, participated in the design of the study, edited the manuscript draft, and secured the funding. All authors read and approved the final manuscript.

\section{Authors' information}

Not applicable.

Ethics approval and consent to participate

Not applicable.

\section{Consent for publication}

Not applicable.

\section{Competing interests}

The authors declare that they have no competing interests.

\section{Publisher's Note}

Springer Nature remains neutral with regard to jurisdictional claims in published maps and institutional affiliations.

Received: 15 October 2018 Accepted: 1 November 2018

Published online: 16 November 2018

\section{References}

Allen SE, Grimshaw HM, Parkinson JA, QuarmbyC. Chemical analysis of ecological materials. Oxford: Blackwell Scientific Publication; 1974.

Armstrong W, Wright EJ, Lthe S, Gaynard TJ. Plant zonation and the effects of the spring-neap tidal cycle on soil aeration in Humber salt marsh. J Ecol. 1985;73:323-39.

Bang JH, Bae M-J, Lee EJ. Plant distribution along an elevational gradient in a macrotidal salt marsh on the west coast of Korea. Aquat Bot. 2018;147:52-60.

Boyle J. A comparison of two methods for estimating the organic matter content of sediments. J Paleolimnol. 2004;31:125-7.

Bray RH, Kurtz LT. Determination of total, organic and extracted forms of phosphorus in soil. Soil Sci. 1945;59:39-45.

Carter MR. Soil sampling and methods of analysis. Boca Raton: Lewis Publishers; 1993.

Crain CM, Silliman BR, Bertness SL, Bertness MD. Physical and biotic drivers of plant distribution across estuarine salinity gradients. Ecology. 2004;85: 2539-49.

Hong MG. Effects of freshwater inflow, salinity, and water level on the growth of common reed in salt marsh. Doctoral dissertation. Seoul: Seoul National University; 2015.

Ihm B-S, Lee J-S, Kim J-W. Coastal vegetation on the western, southern, and eastern coasts of South Korea. J Plant Biol. 2001;44:163-7.

Ihm B-S, Lee J-S, Kim J-W, Kim J-H. Effect of soil factors on vegetation values of salt marsh plant communities: multiple regression model. J Ecol Field Biol. 2006:29:361-4.

Ihm B-S, Lee J-S, Kim J-W, Kim J-H. Coastal plant and soil relationships along the southwestern coast of South Korea. J Plant Biol. 2007;50:331-5.

Isacch JP, Coasta CSB, Rodrigues-Gallego L, Conde D, Escapa M, Gagliardini DA, Iribarne OO. Distribution of saltmarsh plant communities associated with environmental factors along a latitudinal gradient on the south-west Atlantic coast. J Biogeogr. 2006;33:888-900.

Kamphake $\mathrm{L}$, Hannah SA, Cohen JM. Automated analysis for nitrate by hydrazine reduction. Water Res. 1967;1:205-16.

Kim JG, Park JH, Choi BJ, Shim JH, Kwon GJ, Lee BA, Lee YW, Ju EJ. Methods in Ecology. Seoul: Bomoondang; 2004.

Lee J-S, Kim J-W, Lee SH, Myeong H-H, Lee J-Y, Cho JS. Zonation and soil factors of salt marsh halophyte communities. J Ecol Environ. 2016;40:4. 
Lee SH, Lee J-S, Kim JW. Relationship between haplophyte distribution and soil environmental factors in the west coast of South Korea. J Ecol Environ. 2018;42:2.

Lee TB. Colored flora of Korea. Seoul: Hyangmunsa; 2003.

Lissner J, Schierup HH. Effects of salinity on the growth of Phragmites australis. Aquat Bot. 1997;55:247-60.

Min BM. Distribution properties of Phragmites australis and Phacelurus latifolius in the tidal-flat of Suncheon bay. J Ecol Environ. 2015;38:57-65.

Moeller I, Spencert T, French JR. Wind wave attenuation over salt marsh surfaces: preliminary results from Norfolk, England. J Coast Res. 1996;12:1009-16.

R Core Team. R: A language and environment for statistical computing. Vienna: $R$ Foundation for Statistical Computing; 2016

Wolters M, Garbutt A, Bakker JP. Salt-marsh restoration: evaluating the success of de-embankments in northwest Europe. Biol Conserv. 2005;123:249-68.

Yokoyama I, Ohno K, Mochida Y. The influence of environmental factors and zonal distribution of Phragmites australis and Phacelurus latifolius in salt marsh, Central Japan. In: Lieth H, Mochtchenko M, editors. Cash crop halophytes: recent studies. Dordrecht: Springer; 2003. p. 143-9.

Ready to submit your research? Choose BMC and benefit from:

- fast, convenient online submission

- thorough peer review by experienced researchers in your field

- rapid publication on acceptance

- support for research data, including large and complex data types

- gold Open Access which fosters wider collaboration and increased citations

- maximum visibility for your research: over $100 \mathrm{M}$ website views per year

At BMC, research is always in progress.

Learn more biomedcentral.com/submissions 